pÿ I Need to Be Individually Loved, Lord, Let Me Recognize Your pÿGift! : The Gifts of Love in the Soliloquy of Hugh of

Saint-Victor (d. 1141)

Palmen, Ritva Anneli

2020-01

pÿPalmen , R A 2020 , ' I Need to Be Individually Loved, Lord, Let Me Recognize Your Gift! :

The Gifts of Love in the Soliloquy of Hugh of Saint-Victor (d. 1141) ' , Speculum , vol. 95 , no. 1 , pp. 167-185 . https://doi.org/10.1086/706060

http://hdl.handle.net/10138/329749

https://doi.org/10.1086/706060

unspecified

acceptedVersion

Downloaded from Helda, University of Helsinki institutional repository.

This is an electronic reprint of the original article.

This reprint may differ from the original in pagination and typographic detail.

Please cite the original version. 


\title{
"I Need to Be Individually Loved, Lord, Let Me Recognize Your Gift!": The Gifts of Love in the Soliloquy of Hugh of Saint-Victor (d. 1141)
}

\author{
By Ritva Palmén
}

Proponents of the contemporary theory of recognition, Axel Honneth and Charles Taylor in particular, usually assume that humans have a universal need to be recognized as persons. In the sense most relevant for contemporary recognition theory, to recognize someone is to grant another human being a positive normative status based on her personhood. At the most general level, an act of recognition thus means taking and treating the other as a person. In an extended sense, recognition is normally taken to apply to groups and institutions as well. This broadens the scope of recognition considerably and enables recognition-based analyses to deal with a multitude of social, political, and religious entities relevant for human interactions. ${ }^{1}$ Moreover, Paul Ricoeur has argued that recognition may be seen as a form of gift and that gratitude is an adequate response to it, establishing a mutual bond between the parties involved. Hence, a just distance that integrates respect into intimacy lies at the heart of mutuality. ${ }^{2}$ The specific content of these much-discussed theories is not the main focus of this paper, however. I will take their general accounts of recognition and gift exchange as the starting point in order to examine the medieval philosophical psychology of the relationship between the gift and love. ${ }^{3}$ I will show that medieval philosophically-oriented theological texts, particularly the spiritual

I am deeply grateful to the anonymous readers of Speculum, whose detailed and thorough comments significantly helped me to improve the article. I also wish to thank a number of my colleagues at the University of Helsinki for their valuable advice and support, including Simo Knuuttila, Heikki J. Koskinen, Maijastina Kahlos, Hanne Appelqvist, Mikko Posti, Heikki Haara, Risto Saarinen, and Virpi Mäkinen. I also wish to thank Heikki Kuru for his practical assistance.

\footnotetext{
${ }^{1}$ Contemporary recognition theory is based on the foundational work of Charles Taylor, "The Politics of Recognition," in Multiculturalism: Examining the Politics of Recognition, ed. Amy Gutmann (Princeton, 1994), 25-73; and Axel Honneth, The Struggle for Recognition: The Moral Grammar of Social Conflicts (Cambridge, MA, 1995). The theory has been further discussed and developed, e.g., by Heikki Ikäheimo and Arto Laitinen, “Analyzing Recognition: Identification, Acknowledgement, and Recognitive Attitudes towards Persons," in Recognition and Power: Axel Honneth and the Tradition of Critical Social Theory, ed. Bert van den Brink and David Owen (New York, 2007), 33-56. See also Simon Thompson, The Political Theory of Recognition: A Critical Introduction (Cambridge, MA, 2006); Cillian McBride, Recognition (Cambridge, UK, 2013); and Christopher F. Zurn, Axel Honneth: A Critical Theory of the Social (Cambridge, UK, 2015).

${ }^{2}$ Paul Ricoeur, The Course of Recognition (Cambridge, MA, 2007). For an evaluation of Ricoeur's ideas of recognition, see Arto Laitinen, "Paul Ricoeur's Surprising Take on Recognition," Études Ricoeuriennes/Ricoeur Studies 2/1 (2011): 35-50.

${ }^{3}$ For an interesting recent discussion on the medieval idea of the gift and contemporary theories of gift exchange, see Eileen C. Sweeney, "Anselm and the Phenomenology of the Gift in Marcel, Sartre and Marion," in Saint Anselm and His Legacy, ed. Giles E. M. Gasper and Ian Logan (Toronto, 2012), 385404.
} 
literature, contain intricate discussions of the need to be encountered as a person, the nature of the gift, and the dialogical formation of the self, all central issues in modern recognition theories as well. ${ }^{4}$ Several of these medieval texts also discuss such notions as intrapersonal struggle and the vocabulary of submission, notions that represent an early formulation of the vocabulary and terms in which recognition was later discussed.

My claim that the theories of recognition formulated by medieval philosophical thinkers and modern scholars, who are historically wide apart, are relevant to each other will be substantiated by an analysis of the thought of the twelfth-century theologian Hugh of Saint-Victor. ${ }^{5}$ Hugh is known for his systematic theology as well as for a positive assessment of the practical and theoretical sciences of his time. His influence on later medieval spirituality and theology is substantial. In this article, I will focus on his small but influential spiritual treatise Soliloquium de arrha animae (Soliloquy on the Betrothal Gift of the Soul), 6 paying special attention to three aspects of the text: (1) the soul's plea for personal or individual love; (2) the multifaceted idea of the gift; and (3) various descriptions of the acts of recognition.

An analysis of these three aspects of Hugh's treatise reveals important features of his spiritual psychology. I will argue, first, that the text provides a particularly rich

\footnotetext{
${ }^{4} \mathrm{My}$ analysis has two different methodological approaches. First, I examine medieval conceptualizations of interaction between different agents by taking the contemporary theory of recognition as my heuristic starting point. However, I do not claim that medieval theories may be understood as some initial form of a theory of recognition, but I do wish to respect the historical accuracy and context of the text, avoiding anachronisms. Second, modern terminology related to the theory of recognition, such as "recognition," "acknowledgement," and "Anerkennung," has its prehistory in the classical languages. Although Latin verbs such as agnoscere and recognoscere are not used in medieval texts as part of a theory that did not yet exist in its modern form, the analysis of these words in their context still offers valuable information about how they were used to explain different relational accounts, like feudal or marriage contracts, as well as the God-soul relationship. Better understanding of these words may in turn provide more nuanced insights into later terminology for contemporary recognition theorists. For the use of concepts from the contemporary theory of recognition with medieval sources, see R. Palmén and H. J. Koskinen, "Mediated Recognition and the Quest for a Common Rational Field of Discussion in Three Early Medieval Dialogues,” Open Theology 2/1 (2016): 374-90; R. Palmén and H. J. Koskinen, "Recognition Theory and Agreement in Conflict: The Case of Peter Alfonsi's Dialogus contra Iudaeos" (forthcoming, 2020).

${ }^{5}$ Hugh of Saint Victor was a canon regular of the Abbey of Saint-Victor, Paris. Although his place of birth has been disputed, the current consensus is that he was born in Saxony. Hugh arrived in Paris in 1115. He joined the abbey, soon started writing and teaching, was a master by around 1127, and was appointed as head of the school at Saint-Victor by 1133. He died in 1141. For a general account of Hugh's life and works, see the introduction in Paul Rorem, Hugh of St. Victor, Great Medieval Thinkers (Oxford, 2009). In recent years, research has turned increasingly towards Victorine works; the texts have been studiously examined by a group of scholars in the Brepols series Bibliotheca Victorina, volumes 1-26; and translated in the series Victorine Texts in Translation.

${ }^{6}$ Hugo Feiss and Patrice Sicard have edited the Soliloquy in L'oeuvre de Hugues de Saint-Victor (Turnhout, 1997), 2 vols., 1:226-83. The work is cited in these notes as De arrha followed by the page number, a period, and line number. The edition includes translation into French by Dominique Poirel, Henri M. Rochais and Patrice Sicard, with introduction, notes and appendices by Dominique Poirel. The Soliloquy has been translated into English in On love: a selection of works of Hugh, Adam, Achard, Richard, and Godfrey of St. Victor, Victorine Texts in Translation, 2, ed. and trans. Hugh Feiss (New York, 2012), 205-28. It seems that the Soliloquy was among Hugh's last treatises. Over five hundred extant Latin manuscripts from the Middle Ages testify to its popularity throughout the years. For the manuscript transmission and dating of the Soliloquy, see Dominique Poirel's introduction in L'oeuvre, 1:212-15.
}

Speculum 95/1 (January 2020) 
understanding of the intimate dynamics of gift exchange between the soul and God. Second, it serves as an example of a historical articulation of phenomena that have been interpreted in modern terms as a universal human need to be recognized individually as a person.

\section{The Soliloquy: Confidential Discussion with Oneself}

In Hugh's Soliloquy, which belongs to the literary and philosophical genre of dialogue between the Self and the Soul, ${ }^{7}$ the individual addresses herself alone, probing the "secrets of her heart." ${ }^{8}$ The chosen literary tools- the motif of inner conversation and the dialogical form-are efficient ways to represent vividly the inner struggles and dynamics of human beings. While Hugh's Soliloquy includes elements of critical self-assessment, its basic aim is to incite the soul to recognize the gifts given to it by God. At the beginning of the Soliloquy Hugh emphasizes that the subject of discussion is so delicate that it requires that the conversation between the Soul and the Self be private. In this way, embarrassment will not hinder the dialogue from proceeding to the most intimate questions. This metatextual note justifies both the level of confidentiality in the subject and the general tone of the text. The intimacy of the conversation is manifest in the absence of an outside viewer or observing audience. As Hugh writes, there is no need to be ashamed; no one is witnessing the dialogue. $^{9}$

While the Soul of the dialogue is generally diffident, needing love, and selfdoubting, the Self interestingly represents a wise teacher who provides important advice and consolation for the Soul. Having such a conscious character, the Self seems to have special knowledge of divine things as well as of the human soul itself. ${ }^{10}$ The Soul is not left in the lower realms, however, the main aim being to bring it to a better understanding of God and to insert it into the dialogical exchange, in order to lead it to inner renewal and then ecstatic union with its Creator.

The dialogue between the Soul and the Self is set into the wider background context of bridal love, a context derived from the patristic and medieval commentary

\footnotetext{
${ }^{7}$ For this, see Feiss, On Love, 191-92. The genre was initiated by Augustine in his inner dialogue Soliloquia, an inner dialogue being a type of rational discourse within the mind of a single person. For an introduction to and analysis of this genre in Augustine's works, see Brian Stock, Augustine's Inner Dialogue: The Philosophical Soliloquy in Late Antiquity (Cambridge, UK, 2010). Compare Hugh's definition of soliloquy in his De contemplatione et ejus speciebus, ed. Roger Baron (Paris, 1954), 42-44.

${ }^{8}$ Most early manuscripts refer to the disputants using only the initials $A$ and $H$. Some versions refer to Anima and Hugo or Homo. I follow the suggestion made by Feiss, who understands the participants in the dialogue as "the Soul" and "the Self." For this problem, see On Love, 229 n. 6. Although I recognize that ideas of selfhood have gone through significant historical changes and that Hugh does not have a modern idea of the individual self, he nonetheless has a clear interest in the functioning and formation of a person's inner life and awareness. On the idea of constructing the inner self, see Ineke van T'Spijker, Fictions of the Inner Life: Religious Literature and Formation of the Self in the Eleventh and Twelfth Centuries (Turnhout, 2004).

${ }^{9}$ De arrha 226.21-228.27.

${ }^{10}$ For the different ways of understanding the authorial persona in twelfth-century texts and inner dialogues, see Bridget K. Balint, Ordering Chaos: The Self and the Cosmos in Twelfth-Century Latin Prosimetrum (Leiden, 2009), 61-62, 77-106. The authors of this genre strive to combine the ideal of personal authenticity and the wider relevance of the text.
}

Speculum 95/1 (January 2020) 
tradition on the Canticle (the Song of Songs). In this tradition, the biblical narrative of bridal love is usually explained as representing the marriage between the Church and Christ. However, this allegory was then broadened, and bridal love was taken to represent the private relationship between the individual Christian and Christ, so that the bride was understood as the soul and the groom as Christ. This extension, introduced in Origen's third-century commentary in particular, inspired several medieval authors to compose treatises using erotic language for the process that starts with the soul's desire to encounter her groom, includes the spiritual preparation of the soul for intimate communion, and finally ends in mystical union between the bride and the groom. The idea was to understand and explain the ascent of the soul to a state of contemplation and particularly to give an account of the soul's highest attainment, that is, its experience of ecstasy. This ultimate level of spiritual experience was usually described as a kind of alienation of the mind, in which the mind, in a state of spiritual intoxication or excess of joy, forgets itself and the world. ${ }^{11}$

Hugh already employed these ideas and this literary genre in his earlier work $\mathrm{Eu}$ logium sponsi et sponsae (=De amore sponsi ad sponsam; The Praise of the Bridegroom). In this small piece, he briefly elaborates gift vocabulary, the idea of the soul's recognition of the gift, and the soul's need to be individually loved. This love is conceived of as the intimate feeling shared exclusively by two lovers. ${ }^{12}$ Hugh expands this preliminary outline in his Soliloquy on the Betrothal Gift of the Soul by focusing more closely in this later work on the different kinds of gifts and their varying functions in human life. ${ }^{13}$

The core question in his Soliloquy is the nature of love, one of the central themes in Victorine spirituality. ${ }^{14}$ For the Victorines, the experience of love is an elemental part of our psychological makeup. Hugh explains that love is a pleasure of the heart (desiderium) that is directed to an object because of that object. It is an affective disposition towards something, which becomes desire when it moves the subject towards the object. After reaching the object, love is transformed into joy and rest. ${ }^{15}$ In general, for Victorines the experiential dimension of emotions plays a distinctive role in understanding the soul and reality. As Hugh explains in his De sacramentis,

\footnotetext{
${ }^{11}$ Literature on the Canticle's reception history is extensive. For Christian allegorizations and spiritual interpretations of the Song of Songs, see, e.g., Ann W. Astell, The Song of Songs in the Middle Ages (London, 1995).

${ }^{12}$ Eulogium sponsi et sponsae (De amore sponsi ad sponsam), PL 176:987C. On Love, 125-32.

${ }^{13}$ The Soliloquy is a treatise designed for canons regular in Hamersleben, addressed particularly to beloved brother G., who was possibly brother Günther, interim superior of the monastery. The tone of the work indicates that Hugh knew Günther personally as well as some brothers of the monastery, which had been familiar to him since his early adulthood. On Love, 185-86; Oeuvre, 284 nn. 1, 3.

${ }^{14}$ The vocabulary of love is abundant in the Soliloquy. Hugh refers to love with the words caritas, dilectio, and amor. Hugh Feiss points that amor is a disordered or immoderate form of love, whereas dilectio is an ordered, chosen way of love. See On Love, 229. Hugh is not consistent, however, often freely using all these terms as synonymous in his treatise. See, e.g., De arrha 260.518-19: "Nulla dilectio maior, nullus amor sincerior, nulla caritas sanctior, nullus affectus ardentior."

${ }^{15}$ De substantia dilectionis, in Six opuscules spirituels, ed. R. Baron, SC 155 (Paris, 1969), 82.10$12 ; 86.48-73$.
}

Speculum 95/1 (January 2020) 
the experience of one's own feelings, such as joy, sadness, fear, and love, is in fact one of the three main avenues to knowing, the others being sense perception and understanding. ${ }^{16}$

\section{The Need to Love And Be Loved}

Love is arguably one of the most fundamental human emotions. The analyses of this emotion in both contemporary and historical texts offer intimate insights into the elementary psychological mechanisms that human beings are thought to have. Axel Honneth's critical social theory of recognition builds on the idea that the dimension of love and friendship focuses on the other's unique individual personhood and is based on the strong emotional attachments in intimate relationships. Honneth's theory distinguishes three distinct forms of recognition: love, respect, and esteem. These three forms of recognition are essential for individuals' development of a practical identity, that is, a sense of themselves as interacting, moral beings with unique characteristics in the social world. The aim is to explain how individuals come to have an understanding of themselves as individuals in the sphere of social interactions. We become who we are through interactions with others. ${ }^{17}$ In the dimension of respect, recognition focuses on the equal dignity of all. In the dimension of esteem, recognition focuses on who we are, namely, as people of a certain kind with particular identities, based on an estimation of the unequal merits or contributions of these identities. However, the third dimension of recognition, love, includes "special persons," such as friends or lovers, who are irreplaceable from one's own viewpoint and who are of special significance to oneself. In intimate human relationships, there is no duty to love everyone equally. This means that people have unequal personal significance. Thus, while there are differences between people in their relative merits, there are also differences between people in how "special" they are to other individuals, and this constitutes their personal significance for these individuals. ${ }^{18}$

Honneth's writings are deeply influenced by G. W. F. Hegel (1770-1831), who is often referred to as the originator of the notion of recognition (Anerkennung) and the idea of the essentially dialogical conception of human personhood. However, recent research has challenged the assumption that Hegel was the first to formulate

\footnotetext{
${ }^{16}$ De sacramentis 1.10.2., PL 176:328C. Hugh's successor, Richard of Saint-Victor, put even more emphasis on human experience, claiming that for most people one's daily experience is the most persuasive way to prove things (probare), and the proof is thus more certain than a proof gained by reasoning only. The experience of love interests Richard particularly: he claims that manifold experience teaches us that nothing is more pleasant in human life than charity. In De Trinitate, he uses examples of the experience of love as a foundation for seeking reasons (rationes) established within the relationships among the persons of the Trinity, and De IV gradibus violentae caritatis compares aspects of profane love to the love of God. See Ritva Palmén, Richard of St. Victor's Theory of Imagination (Leiden, 2014), 73-76; On Love, general introduction, 36-42.

${ }^{17}$ Honneth, Struggle for Recognition, 95-130; Zurn, Axel Honneth, 24.

${ }^{18}$ As Arto Laitinen explains, different kinds of recognition differ in relation to whether the agents are related qua persons ("policy of universality") or qua persons having particular characteristics or features ("policy of particularities") or qua individuals who are singled out ("policy of singularity"). Respect, social esteem, and love exemplify these different categories. See Laitinen, "Recognition-a Response to Value or a Precondition of Personhood?," Inquiry 45/4 (2002): 463-78, esp. 470, 472. See also Zurn, Axel Honneth, 28-42.
} 
this conception, claiming that the intellectual roots of the conception of recognition are found in classical, medieval, and early modern sources. ${ }^{19}$ My study hypothesizes that an analysis of the role of such emotions as love in medieval and Renaissance theories of self and identity can offer an important new understanding of recognition relations in pre-Hegelian contexts. It can also reveal how the self is formed in dialogical relationships. ${ }^{20}$ Taking Hugh of Saint-Victor as my example, I will demonstrate how his Soliloquy offers an illustration of the historical articulation of the idea of the need to love and be loved.

Hugh maintains that love itself requires reciprocity, that is, two-way communication and the mutual exchange of affects. Both the plea for being uniquely loved and the reciprocity of love entail an individual's distinctive subjective experience. Not surprisingly, Hugh shows a strong interest in analyzing introspective subjective feelings and the first-person experience of love, an analysis that I claim reinforces the idea of a person's unique identity.

The question of identity formation can be detected in the main thrust of the Soliloquy, which deals with the soul's continual drive to find perfect love. The incessant urge to have a concrete, sensible object of love is presented as a basic natural need for all. Hugh's Soliloquy situates this experience within the spheres of both human and spiritual love. This becomes evident in comparison with two major medieval theologians, Anselm of Canterbury and Bernard of Clairvaux. As Eileen Sweeney has shown, Anselm's fellow monks request his individual love, which he denies in his letters, maintaining that intense love and attachment should manifest itself at the general level rather than individually. Feelings towards one individual can be transferred without loss to another person, since all the members of the community are mutually loved in Christ. ${ }^{21}$ Bernard of Clairvaux was famous for his theology of love, which shows poignant attention to the experiential basis of emotions. Bernard acknowledges, as does Hugh, the affective experience of love, indicating how important subjective involvement is for a religious person. ${ }^{22}$ However, Bernard's formulations do not express a concern to be uniquely loved or individually noticed, as Hugh's account does. In fact, in his small tractate De gradibus humilitatis et superbiae, Bernard enumerates and examines twelve degrees, or steps, of pride, mentioning the desire for uniqueness (singularitas) as a form of pride. The person with

\footnotetext{
${ }^{19}$ For a recent substantial study of the initial forms of recognition terminology, see Risto Saarinen, Religious Recognition: A Historical and Systematic Study (Oxford, 2016). Saarinen analyzes, among other works, twelfth-century spiritual texts written by Bernard of Clairvaux.

${ }^{20}$ For this idea in modern discussions, see the important study by Dan Zahavi, Self and Other: Exploring Subjectivity, Empathy, and Shame (Oxford, 2014). Note that in this debate the self and its formation do not refer to Hugh's fictive Self in the Soliloquy.

${ }^{21}$ See Eileen C. Sweeney, Anselm of Canterbury and the Desire for the Word (Washington, DC, 2012), 48-54.

${ }^{22}$ For a useful discussion on Bernard and other twelfth-century authors interested in the analysis of love, see Constant J. Mews, "Bernard of Clairvaux, Peter Abelard and Heloise on the Definition of Love," Revista Portuguesa de Filosofia (2004): 633-60. The literature on twelfth-century ideas of love is extensive. See, for example, Jean Leclercq, Monks and Love in Twelfth-Century France (Oxford, 1979); Julian P. Haseldine, "Monastic Friendship in Theory and in Action in the Twelfth Century," in Friendship in the Middle Ages and Early Modern Age: Explorations of a Fundamental Ethical Discourse, ed. Albrecht Classen and Marilyn Sandidge (Berlin, 2011), 349-94.
}

Speculum 95/1 (January 2020) 
an urge to "singularity" is anxious to be seen as better than others. He wishes to say, "I am not like other people." 23

Bernard offers a profound analysis of the nature of love, but as the Soliloquium reveals, the topic of love is more personal for Hugh. In a dialogical exchange, the Self addresses the Soul, saying that it is well aware how much the Soul sees and enjoys the visible world. Now it demands that the Soul confess without shame what it loves the most and most uniquely, something visible or perhaps something else that it loves more than any visible thing. ${ }^{24}$ Hugh's text clearly reveals that love can find no satisfaction or consummation. This is shown in the Soul's confession that it can neither be without love nor find a true love. What the Soul can love does not satisfy it, and the Soul cannot love what will satisfy it. It cannot truly love anything visible, since it either loses its love when its object perishes or the love itself changes when something more enjoyable comes along. The Soul understands that it cannot love anything temporal, but it still finds it very difficult to love something that cannot be seen. But no one can be happy without love. As the Soul notes, it is inhuman to despise the peace of the community and miserable to love oneself alone. ${ }^{25}$ Love would cease to be love if it did not diffuse its power of affection (vim dilectionem non diffundit) towards another, equal companion. ${ }^{26}$ By definition, love is something that requires a dialogical relationship since it is a reciprocal emotion.

The dynamic between seeing and loving is a recurrent theme in the text. Hugh explains that the Soul has an urge to see her lover, but that he cannot be seen-which is just as well, as the Soul cannot see herself, either. However, as the Self reminds the Soul, the lover (or spouse) has seen the Soul, since otherwise he would not love the Soul. If the Soul could see the elegance and beauty of her spouse, she would be convinced that she is a uniquely beautiful and singular being, because she is loved by such a spouse. Being capable of drawing the spouse towards her, the Soul is therefore more beautiful and admirable than other souls. ${ }^{27}$

In modern terms, the basic question of identity constitution concerns the idea of the self and its foundation either as an autonomous or heteronomic entity. As both Axel Honneth and Charles Taylor argue, individual identity formation emerges in heteronomic dialogue with others. Both these thinkers have a view of people as essentially social beings whose psychological and social identities, capacities, and

\footnotetext{
${ }^{23}$ De gradibus humilitatis et superbiae tractatus, PL 182:965BC. For the idea of singularity as a vice in medieval monasticism, see Gert Melville, "'Singularitas' and Community: About a Relationship of Community and Complement in Medieval Convents," in Potency of the Common: Intercultural Perspectives about Community and Individuality, ed. Gert Melville and Carlos Ruta (Berlin, 2016), 189200.

${ }^{24}$ De arrha $228.37-41$.

${ }^{25}$ De arrha $230.66-73$.

${ }^{26}$ De arrha 232.91-94. Hugh has a standard Neoplatonic idea of the diffusive character of love. In Christian Neoplatonism, God was presented as a self-diffusive power, which not only radiates its goodness and love but also draws all beings back towards itself. See, e.g., Marie-Dominique Chenu, Nature, Man, and Society in the Twelfth Century: Essays on New Theological Perspectives in the Latin West, selected, ed., and transl. by Jerome Taylor and Lester K. Little (Toronto, 1997), 80-81, 85.

${ }^{27}$ De arrha 234.122-29.
} 
statuses are constituted through processes of interpersonal dialogical interaction. ${ }^{28}$ The idea that one is able to know oneself through others was already articulated in classical literature. ${ }^{29}$ While dialogical interaction is essential in Hugh's theory, at the same time it seems fundamental for him to underline that the soul must turn inwardly to understand itself in order to have a certain amount of autonomy. Hugh also emphasizes the importance of the right kind of self-love. The clearly stated desire to form a loving relationship truly worthy of affection is balanced by the equally clearly stated principle to turn to contemplation of the inner depths of one's heart. ${ }^{30}$ As is usual in twelfth-century spiritual treatises that were inspired by Augustine's writings, this thread of thought manifests itself in an emphasis on inwardness and the quest to know oneself in order to ascend to an understanding of divinity. ${ }^{31}$ Even so, Hugh's analysis of love also strongly indicates the importance of heteronomic relations and interdependence with other people, the world, and God. These webs of relations are fundamental to a person's full realization as a human being. Hugh's understanding that the Soul may learn to love herself through the gaze of her lover shows both the heteronomic nature of love and the relation between the soul and the Other.

Hugh considers both the idea of knowing the self through others and the concept of direct self-knowledge. He introduces the basic question of the formation of the self by discussing the recognition of the human face (facies). Referring to the visible beauty of loveable objects, the Self asks why the Soul does not love itself, its own face in particular, since the (visible) face surpasses the beauty of all visible things. The Soul replies that the eye can see all things except itself. One's apprehension of one's own face is ultimately dependent on other people's indications. These are usually communicated through their descriptions of a person's countenance. We are unable to understand even our own heart without other people's feedback. ${ }^{32}$

\footnotetext{
${ }^{28}$ Taylor, "Politics of Recognition," 32: "People do not acquire the languages needed for selfdefinition on their own. Rather, we are introduced to them through interaction with others who matter to us-what George Herbert Mead called "significant others." The genesis of the human mind is in this sense not monological, not something each person accomplishes on his or her own, but dialogical."

${ }^{29}$ For the Platonist, Aristotelian, and Stoic traditions of knowing the self through others, see Richard Sorabji, Self: Ancient and Modern Insights about Individuality, Life and Death (Oxford, 2006), 23044.

${ }^{30}$ The soul expresses her need to form a loving relationship worthy of affection several times. See, e.g., De arrha 228.42-45; 238.186-94. The text also manifests the urge to turn towards contemplation of oneself. See De arrha 230.78-80: "O si facies tuam uideres, agnosceres certe quanta reprehensione digna fueras, cum aliquid extra te amore tuo dignum existimabas." This same emphasis on knowing oneself occurs at the beginning of Hugh's Didascalicon 1.1.4.3-12, where he refers to the famous Greek maxim "know thyself" and considers the knowledge of oneself as the first way to understand one's origin and the origin of the world. See Didascalicon de studio legendi, ed. Charles Henry Buttimer (Washington, DC, 1939). In his De tribus diebus 17.2, 36-37.604-614, Hugh considers the knowledge of oneself as the path to all wisdom. The door to contemplation opens for the person who enters with the aim of knowing himself. See De tribus diebus, CCCM 177 (Turnhout, 2002).

${ }^{31}$ See the classic three-volume study of the idea of Christian Socratism by Pierre Courcelle, Connarstoi toi-même de Socrate à Saint Bernard (Paris, 1974-75). For Augustine's influence on Hugh's De arrha, see On Love, 197-200.

${ }^{32}$ De arrha Sicard, 230.81-232.89. In this example, Hugh utilizes the medieval optical theory of extramission, which held that the rays emanate from the eyes of the observer, reflecting objects and
}

Speculum 95/1 (January 2020) 
Furthermore, the perfect Christian life entails that the individual use Holy Scripture as a mirror to see one's own face. Through this mirror, a person learns to see if there is anything unfitting in herself. ${ }^{33}$

Although the main intention of the work is to highlight the reciprocal nature of love and self-realization, the constant turning towards reflection on the inner structures and life of the soul emphasizes the primacy of self-love. Stressing the significance of having the right kind of affection towards oneself, the Self reminds the Soul how important it is to consider one's inner life and to recognize one's own dignity in order to avoid loving things that are beneath oneself and which would thus cause harm. In this endeavor, it is important to realize how powerful an affection love is. Love is like a fire that makes the lover similar to the object of love. This is because association through love somehow transforms an individual and makes her more closely resemble the loved one. A negligent person may be unable to contemplate her own inner depths, but she may always value herself on the basis of someone else's (for example, her spouse's) judgment. ${ }^{34}$ This concept resonates well with the modern idea of recognition, which stresses both self-confidence and self-respect as well as the importance of expressing one's desires and needs in a dialogical relationship without the fear of being abandoned as a result. ${ }^{35}$

\section{GIFTS OF Love}

Hugh's discussion of the human need to love and be loved as well as his requirement that the Soul see the lover is further conceptualized in the Soliloquy as a form of gift exchange. Hugh explains that although the lover himself cannot be seen, his gifts are still perceptible. Through these gifts, a person may infer the love and goodness of her lover. As Hugh Feiss points out, Hugh's gift vocabulary derives from Augustine, who distinguishes between "pledge" (pignus) and "earnest money" (arrha). According to Augustine, a pledge is returned after the thing itself is given. However, earnest money is a part or portion of the things that are promised as a gift. When the thing itself is given, the gift is completed, and the earnest money is not taken away or changed. ${ }^{36}$ In Hugh's text, this arrha is specifically connected to marriage gifts. Occasionally Hugh also refers to pignus, beneficium, munera, and dona, all of which can be used to indicate the gifts that the soul receives from God. Hugh shows awareness that all these words have their own distinct spheres of use in worldly life. Beneficium is a form of gift or favor given by a lord to his servant, munera are gifts that are received from a friend, dona and arrha are marriage gifts, and pignus is

\footnotetext{
making them visible to the perceiver. For medieval optical theories, see David C. Lindberg, "The Science of Optics," in Science in the Middle Ages, ed. Lindberg (Chicago, 1978), 338-68.

${ }^{33}$ De arrha $270.686-88$.

${ }^{34}$ De arrha 232.106-12: "Ea uis amoris est, ut talem te esse necesse sit, quale illud est quod amas, et cui pre affectum coniungeris, in ipsius similitudinem ipsa quodammodo dilectionis societate transformaris"; 234.118-21: "cur saltem quid de te estimare debeas ex indicio alieno non perpendis?"

${ }^{35}$ Honneth, Struggle for Recognition, 95-97, 107.

${ }^{36}$ On Love, 192. See Augustine, Sermo 156, in Sancti Aurelii Augustini sermones, ed. Gert Partoens, CCSL $41 \mathrm{Ba}$ (Turnhout, 2008), 159. The background of this theme is biblical: Ephesians 1.14 asks, "Who is the pledge ( $\tau \dot{v} v \dot{\alpha} \rho \rho \alpha \beta \tilde{\omega} v \alpha$ ) of our inheritance?" and 2 Corinthians 5.5 mentions that God has given us the spirit as a pledge $(\dot{\alpha} \rho \rho \alpha \beta \tilde{\omega} v \alpha)$.
}

Speculum 95/1 (January 2020) 
mentioned as love's gift. ${ }^{37}$ By presenting different pairs of givers and recipients of gifts in human life and by varying his gift vocabulary, Hugh is able to present the multifariousness of gift exchange in the relation between the soul and God as well.

The plea to be individually loved functions as a preamble for Hugh's division of gift into three categories that serve as a basic structure for understanding both the relation between God and people and the nature of love. The individual receives gifts commonly, specially, and individually. Common gifts are those granted for all to use, special gifts are given to a specific community, and individual gifts are conveyed to each person as her own. ${ }^{38}$ Hugh starts by discussing the most general form of gift, the common, and then gradually proceeds to deal with more intimate forms of gifts and love.

One of the main problems in the Soliloquy concerns the abstract nature of gifts. The Soul must learn to discern different kinds of gifts and comprehend their nature accurately. The stakes are high, since the gifts represent the central questions of religious life, and understanding their proper nature determines the way of being a religious person. Hugh considers that the most easily known are common gifts, which means all visible goods. He pays much attention to these common gifts, which are granted to all creatures and are perceptible in the visible world. They include supplies, food, drink, light, warmth, the changing seasons, and pleasurable things.

This emphasis on perceptible goods relates to Hugh's natural theology, which refers to the fact that natural means and evidence available to natural faculties may bring one some knowledge of God. Hugh uses the same principles in his argument on common goods as he did in his little treatise De tribus diebus, in which his general method is to proceed from visible things to investigate invisible things, the Trinity in particular. The basic premise in De tribus as well as in the Soliloquy comes from Romans 1.20, which states that the Creator himself may be perceived when the world is contemplated. The Word cannot be seen, but he can be seen through what he has made. The argument is essentially based on the idea of causation. It supposes that some features of created things allow us to infer some characteristics of their Creator. Thus, nature itself bestows evidence for both God's existence and his various attributes. ${ }^{39}$ In the Soliloquy, the visible things of the world are interpreted as gifts of God.

By receiving and understanding the gifts of nature, the individual also understands something about the creator of the world. The idea of the gift involves an important affective dimension in relationships between creation, God, and other people. If the Soul recognizes the affection of her lover in the gifts received, the Soul may more aptly love him. First of all, the Soul should look at the entire visible world and see how useful and delightful it is. The whole circle of life and the seasons serve the human being abundantly. The receiving of common gifts does not entail detailed

\footnotetext{
${ }^{37}$ See, for example, De arrha 236.170-71; 238.182-85, 238.191.

${ }^{38} \mathrm{De}$ arrha 250.361-66. These three kinds or levels of love resonate nicely with Axel Honneth's idea of three dimensions of recognition: respect, esteem, and love; see pp. 167, 171-72.

${ }^{39}$ In De tribus diebus, Hugh argues that the three invisible aspects of God are his power (potentia), wisdom (sapientia), and kindness (benignitas) and then aims to show how they can be perceived in the created world: De tribus diebus 1.2, 3-4. The Soliloquy's terminology has some overlap with De tribus.
}

Speculum 95/1 (January 2020) 
knowledge about their giver; for instance, the Soul is not yet able to recognize (agnoscere) the giver who remains hidden. However, the Soul can reason that no human being is capable of giving such things, but that they were bestowed by someone else's favor (beneficium). The essential relation between the Soul and God is established through affective attachment. The gift is so great that it would be stupid not to desire (concupiscere) the love (amorem) of such a giver more. ${ }^{40}$

Common gifts encompass all visible phenomena; the whole visible world is said to be subject to the Soul. Its objects are beautiful, their quantity is great, and they are both useful and good. These things should be loved as subjects, servants, and gifts. Offering more varied vocabulary, Hugh further relates that these gifts are like a betrothal gift (arram sponsi), the gifts of a friend (munera amici), or the favors of a lord (beneficia domini). The Soul should love the giver of these gifts, not the gifts themselves. The Self commends wholesome love that is attached to one who alone is loved. ${ }^{41}$ Hugh's rich vocabulary indicates that while the gifts are common, that is, shared by all, the relationship between the giver and the receiver is still intimate.

These formulations interestingly manifest the contextualization of Hugh's thought in the cultural framework of feudal society. ${ }^{42}$ Risto Saarinen has shown how Hugh's contemporary, the theologian Bernard of Clairvaux, employed the terminology of feudovassalic institutions in order to illustrate and explain religious bonds. ${ }^{43}$ Hugh's analysis of the gift reveals the same linguistic inclination. Although the idea of gifts is presented in a religious context, the underlying current of establishing a bond between the representatives of lower and higher rank is surprisingly similar to that which is used in medieval feudal systems for determining the relationships between lords and vassals. The lord gives a gift (beneficium) to the vassal, who in turn recognizes his lord. As Saarinen points out, the feudal phrase used of the vassal (se commendare) is normally replaced in medieval religious texts by agnosco or recognosco. Thus, religious commendatio arises starting with God "commending" the servant and the servant "recognizing" God. As in the feudal commendatio, the lord's act of commending is accompanied by benefits or gifts bestowed on the servant. ${ }^{44}$

${ }^{40}$ De arrha 236.154-63. Note the interesting word choice (concupiscere), which refers to orientation toward something that is considered pleasurable or good. Peter Abelard notes that people should love God as a friend (amor amicitia), and the desire for possession (amor concupiscentia) should be excluded. Hugh disagrees with Abelard by stressing that all love desires good: De sacramentis, PL 176:534. For this discussion and its twelfth-century context, see John Burnaby, Amor Dei: A Study of the Religion of St. Augustine (Eugene, OR, 2007), 257. For the later medieval distinction between amicable and concupiscent love, see Simo Knuuttila, Emotions in Ancient and Medieval Philosophy (Oxford, 2004), 27173. For further discussion, see pp. 181-82.

${ }^{41}$ De arrha $236.165-71 ; 238.201-2$. For the verb commendo and the noun commendatio in medieval social practices, see Risto Saarinen, Recognition, 58-62. As Saarinen concludes, these terms express a cluster of social practices and philosophical conceptions in which people either give themselves to the service of others or achieve a new self-understanding as a result of this act.

42 The notion of feudalism has been a much-discussed topic in recent historiographical literature. For a critical, extensive overview of medieval societal systems, see Susan Reynolds, Fiefs and Vassals: The Medieval Evidence Reinterpreted (Oxford, 1994), 1-16; 260-322.

${ }^{43}$ Saarinen, Recognition, 58-69.

${ }^{44}$ Saarinen, Recognition, 62. For the feudal terminology of commendatio and beneficium and several examples of charters of medieval oaths, see F. L. Ganshof, Feudalism, trans. Philip Grierson, 3rd ed. (New York, 1964), 5-9, 106-7. While Saarinen offers an initial account of feudalism and recognition

Speculum 95/1 (January 2020) 
The more difficult predicament in love is a desire to be specially or even individually loved. Hugh's text gets more personal. It would be terrible for a person to choose and uniquely love someone and find out that she herself is not the only loved one. This is exactly the case with the betrothal gift, that is, the common gift, since it is given to all creatures, even bestial people and animals. The sun rises for all and there is the same food and drink for all. This kind of common love does not enflame the Soul to love the giver of the gift individually. Within this setting, the Soul finds it very difficult to understand how one may glory in the privilege of individual love (privilegium singularis amoris); why would the Soul love individually, if the Soul was not loved in the same way in return? ${ }^{45}$

The Self asks the Soul to imagine a solitary life without other people or animals and doubts whether owning all the riches of the world alone would actually please anyone; shared human life is certainly more useful and pleasant. However, this kind of mutual ownership of all things and the sharing of company is still insufficient for the Soul. It is possible to discern a kind of love in common having all the things that foster life, yet the problem remains that these things are available to many while the Soul does not have an established privilege of love that is individual. ${ }^{46}$ For Hugh, the communal life does not satisfy the soul's need for a specific attachment.

The idea of common love and common gifts is next compared with special love and special gifts, respectively. In contrast with common love, the creator has indeed granted people special love, enabling them to rise above other creatures. The objective of love is now more restricted. Still, this special love does not reassure the Soul, since other people have a value equal to that of the Soul in that there is no qualifying principle that distinguishes them from one another. The Soul is worried that in this community of people it might lose its uniqueness and be contaminated by some bad or unwanted qualities of other people when it comes in contact with them. ${ }^{47}$ As the Soul notes, community of people includes criminals and unclean people as well. The Self's answer shows that Hugh has a clear tendency to underline the importance of social life and shared feelings, joy and love in particular. The special love refers to the company of other people and love experienced together. When the love is shared with many others, it increases. If spiritual love is communally shared it becomes more pleasant in a singular way. The love does not decrease with the participation of many, since the spouse is said to love all people through every single person. ${ }^{48}$ The singularity of love remains, since nothing is loved without the Soul. The spouse's love is partitioned and divided among all. Individual love may flourish within communal love, because all spiritual people love the spouse uniquely and are themselves uniquely loved, and through this love they love together as one and become one. ${ }^{49}$ Even the lives of the wicked contribute to the

\footnotetext{
terminology in his book, the analysis of similarities between feudal phrases and religious bonds deserves more attention.

${ }^{45}$ De arrha $240.208-20$.

${ }^{46}$ De arrha 242.236-38, 242.254-67.

${ }^{47}$ De arrha 244.269-73.

${ }^{48}$ Cf. De tribus diebus $15,33.526-28$, which states that all things have been made one by one, such that seeing the totality enables each to be admired individually.

${ }^{49}$ De arrha 246.317-20: "qui conparticipant, affectus dilectionis expanditur, caritas gaudium et suauitas ampliatur. Spiritualis namque amor tunc melius cuique fit singularis, quando omnibus est
}

Speculum 95/1 (January 2020) 
common good, challenging good people to seek the greater good, admonishing the good to love the virtues more passionately. ${ }^{50}$

Hugh's earlier work, The Praise of the Bridegroom, has different definitions of common and special love, although the Soul is said to be dowered by both common and special kinds of gifts given by God. The common gift shared by all refers to the fact that we are born, have sensations, know, and discern. Special love is said explicitly to be granted to Christians only. Hugh writes that Christians have also received a special gift through the fact that they have been reborn, attained remission of sins, and received gifts of the virtues. ${ }^{51}$ This idea of the Christian community as a separate and distinctly esteemed group of people is not explicitly taken up in the Soliloquy.

The last and most personal form of love, unique or individual love, may be found within special love. This unique love differs from the common and special forms of love, since the mutuality of loving relationships with the spouse and each individual enables the love "to be unique, but not private; individual, but not solitary; participated in, but not divided; common and individual for all and complete for each." 52 The unique, personal, and most intimate love is thus available to the Soul in a special community of other people. Interestingly enough, this kind of love, through shared special love and community, is unsatisfying for the Soul without a personal experiential response. Hugh acknowledges that there is a subjective first-person experience of love that is fundamental for the Soul. Therefore, the Soul still wishes to feel the spouse's intimate attendance and know whether he is "affectively and effectively" present with the one he loves. ${ }^{53}$ The personal knowledge of love, the actual experience of it, is still needed. This emphasis on personal experience resembles Bernard Clairvaux's thinking in that the higher spiritual affect is the feeling through which one is aware of an act of divine acceptance and love. This kind of affective self-awareness is the fundamental element of the spiritual experience of love. ${ }^{54}$

The Self in the text proceeds to evoke the feeling of love by reiterating that the existence of the Soul is a gift given individually to each soul. God wanted the person to be rather than not to be, and the existence he gave is excellent and beautiful. The human being has nothing to give back except her individual love. In this concept we can discern the hierarchical system of gifts and the basic Victorine anthropological scheme. In his work Hugh employs the idea of the threefold powers of the soul, which are said to vivify bodies. The first power of the soul supplies life to an existing body in order to let it grow and be nourished. The second power of

\footnotetext{
communis; nec participatione plurium minuitur. . . sponsus tuus in omnibus diliget te, quos diligit propter te, ac per hoc etiam singulariter diligit te." 248.333-35: "Ergo omnes unum unice diligant, ut omnes ab uno unice diligantur."

${ }^{50}$ De arrha 244.277-85.

${ }^{51}$ Eulogium sponsi et sponsae (De amore sponsi ad sponsam), PL 176:987CD: "Sed est quaedam arrha communis, quaedam specialis. Communis arrha est quod nati sumus, quod sentimus, quod sapimus, quod discernimus. Specialis arrha est, quod regenerati sumus, quod remissionem peccatorum consecuti sumus, quod charismata virtutum accepimus."

${ }^{52}$ De arrha $248.337-340$.

${ }^{53}$ De arrha 248.349-52.

${ }^{54}$ Knuuttila, Emotions, 195-99.
} 
the soul provides sense perception, while the third power of the soul is the distinctively human power to reason and understand. ${ }^{55}$ These three powers can be seen as gifts at different levels granted to every person individually. The spouse adorns the bride outwardly through giving her senses and inwardly by providing her with wisdom. ${ }^{56}$

A strong Christological undercurrent comes into the play when the Soul is confronted by the fact of its own vileness as a result of the Fall. After lecturing on the kinds of gifts the Soul has received, the Self warns the Soul against prostitution and the danger of forgetting the spouse as well as his gifts. Most of all, the atonement of fallen man manifests how greatly God has loved mankind. After she understands all this the Soul is even provoked to say how much she loves her own fault (amare incipio culpam meam); she has fallen happily and risen more happily after her fall, since now she understands how much Christ loves the Soul. God chose to die for her so that he would not lose her. The experience of this kind of love despite the danger into which the Soul had fallen has led the Soul to recognize Christ's love. ${ }^{57}$

The vocabulary of bridal love is noticeable when the Soul is asked to cleanse, prepare, and adorn itself to be able finally to enter the bedchamber and meet the heavenly spouse without being ashamed. ${ }^{58}$ The last chapters of the Soliloquy describe the sweet taste of the presence of God and the alienation of the mind, following traditional motifs of spiritual literature. While the theme of erotic feeling occurs frequently in medieval spiritual commentary literature on the Song of Songs, and while Hugh is clearly familiar with that tradition, his emphasis on the personal experience of love and its nature is an original contribution. This originality rises from his understanding of the importance of the first-person experience and the fundamentally reciprocal nature of love. Furthermore, Hugh's idea that love can be individual and yet common represents a novel articulation that differs from the standard views, which ask the individual to be satisfied with communal and more general love and fail to recognize the human need for unique love. ${ }^{59}$

\section{Recognition of Gifts And Their Giver}

As shown above, the multifaceted idea of the gift plays a major role in the Soliloquy. Modern gift theories hold that a gift establishes a mutually affective bond between the giver and receiver and, when the receiver accepts the gift, the receiver and the giver mutually recognize one another. A gift is like a seal in an alliance; a person's own self is given in the gift. ${ }^{60}$ Hugh explains the dynamics of gift exchange

\footnotetext{
${ }^{55}$ Didascalicon 1.1.7-10. Cf. Boethius's In Porphyrii Isagogen commentorum editio secunda 1.1, ed. Samuel Brandt, CSEL (Vienna, 1906), 48:136 (PL 44:71A).

${ }^{56}$ De arrha $254.436-46$.

${ }^{57}$ De arrha $258.510-11 ; 260.512-18$.

${ }^{58}$ De arrha $264.572-75$.

${ }^{59}$ For Anselm's idea of communal love, see p. 172.

${ }^{60}$ For modern accounts of gift exchange and the act of recognition, see in particular Marcel Hénaff, The Price of Truth: Gift, Money, and Philosophy, trans. Jean-Louis Morhange with Anne-Marie Feenberg-Dibon (Stanford, 2010). For the idea of the gift in a historical and theological context, see the recent monograph by Risto Saarinen, Luther and the Gift (Tübingen, 2017). Modern philosophers
}

Speculum 95/1 (January 2020) 
similarly: the Soul should love the affection of the giver more than the gifts. If the receiver of the gift cannot respond to the giver by experiencing the right affection, he should refuse the gifts. ${ }^{61}$

What becomes evident is that receiving the gift requires the right kind of response by the receiver. In the Soliloquy, this response is conceptualized as recognizing (agnoscere) the gift or its giver (the Lord). The act of recognition in this process can be defined as an upward relation, the lower agent (the Soul) being the one that recognizes the upper agent (God). The most significant difference from the modern theory of recognition concerns the nature of the status change, since it is not the object of recognition but the recognizer that undergoes this change. This act entails a performative level, in which a gift (beneficium) is given and received. For instance, a servant recognizes his lord and a Christian recognizes God in this manner. This kind of recognition does not produce equality: the servant remains lower than the lord and a Christian does not become God. ${ }^{62}$ However, the standard paradigm in modern recognition theory considers that it is the object of recognition who submits to a change in status. ${ }^{63}$

I wish next to show that Hugh's idea of gift exchange manifests various dimensions of recognition. In this analysis, I will distinguish three components of recognition: affective, cognitive, and performative. (1) Most of those who endorse the relevance of love also stress the importance of the affective dimension for all subsequent forms of recognition. (2) Recognition necessarily involves a cognitive component, that is, the existence of certain conceptual preconditions. In this context, this means that the content of recognition has been understood adequately. It also embraces the idea of identification, that is, something or someone has been noted or identified correctly in the act of recognition. (3) Recognition not only includes a rationale for recognition with appropriate affect, but also refers to the act of recognition itself, a performance or transformation that the agents undergo in recognition. The performative component establishes a transformation and change in the relationship between God and a human being. While this performative dimension

\footnotetext{
have also addressed the paradoxical and even pathological elements in gift exchange; see, e.g., Jason Alvis, Marion and Derrida on the Gift and Desire: Debating the Generosity of Things (n.p., 2016).

${ }^{61}$ De arrha 238.175-76. In Hugh's emphasis on the love for the giver instead of mere love for the gift, one can discern an early articulation of the later standard distinction between loving someone for the sake of one's own interests and loving someone for his own sake. This distinction was later conceptualized as "the love of concupiscence" and "the love of benevolence or friendship." For this distinction in Thomas Aquinas, see his Summa theologiae II, II, q. 23, 1. For a discussion of the forms of love in the Victorines and Aquinas and a selection of secondary literature, see On Love, 105-9.

${ }^{62}$ See Saarinen, Recognition, 32: "In an upward recognition, a person of lower status recognizes a person of higher status.... [The] focus [is] on the performative move of the recognizer, who is assumed to represent the default perspective of the act in question. This performative move need not be the first move in the entire process. Something like a horizon of expectation can precede it. For instance, the lord expects his subjects to recognize him and he may have promised some favor for those who do so."

${ }^{63}$ This model has also received some criticism. For instance, Cillian McBride has pointed out that in seeking recognition from someone, I am already recognizing his authority over me. In this model, the act of recognition cannot simply be defined as a relation between the subject and object of recognition, but it is more like a mutual process that involves agency from both agents and complicated power structures. McBride also notes that my desire for recognition might itself be a result of social domination: McBride, Recognition, 6.
} 
usually appears as a part of the conversion narrative, its elements can also be seen in prayer and liturgy, both of which are essential components of Christian religious life. ${ }^{64}$ For Hugh, the act of gift exchange involves both the subjective attachment of love as well as an intellectual level of understanding. Because of the gift exchange, the receiver of the gift undergoes spiritual renewal, which manifests in a performative act of confession.

In the paradigmatic case of the Soliloquy, the person recognizes the giver through the gift. The Self requests that the Soul recognize her spouse through the betrothal gift. ${ }^{65}$ Since the kinds of gifts are numerous (common, special, and individual) and can be said to entail different levels of love, the venues for recognition are also manifold. By recognizing the gift, the Soul discovers how it can learn to love God. ${ }^{66}$ The recognition of the gift includes both affective and cognitive components.

Interestingly, Hugh also deals with the problem of misrecognition. In the examples he cites, misrecognition seems to be the result of a failure in the cognitive component of recognition. In the early stage of the spiritual process, the Soul seeks individual love, but is not yet able to recognize the giver of the gift. Although the Soul receives the gift (beneficium), it does not recognize its source. ${ }^{67}$ Later, when the Soul understands that it has received gifts and is aware of the giver, it is still not able to recognize the unique nature of the gift and, accordingly, the singularity of God's love. ${ }^{68}$ The text seems to say that some people are too simple-minded ever to be able to recognize the gifts and their giver, but remain looking downward towards themselves. However, God loves both those who strive to acknowledge him as well as those who cannot. ${ }^{69}$

Hugh strongly emphasizes, in particular, the affective attachment of both the recognizer (the Soul) and the object of recognition (God, the spouse) in several examples. The Soul is said to desire passionately to please God, since it recognizes God's charity as kind and pleasant. ${ }^{70}$ The Soul would never have recognized God's love so well had it not experienced this love even in its own wrongdoing and sinning. ${ }^{71}$ The Soul may also recognize God's love even when undergoing bad experiences in life. This love is understood and felt as unique, and we may love God uniquely in return for both the good and bad things in our lives. Hugh explains that the Lord has granted many good things for the Soul singularly (he mentions such things as

\footnotetext{
${ }^{64}$ For the performative component of recognition, see Saarinen, Recognition, 199-203.

${ }^{65}$ De arrha 276.767-68: "Ecce habes, anima mea, arram tuam, et in arra tua cognoscis sponsum tuum.”

${ }^{66}$ De arrha 234.135-36: "Fortassis in ipso munere eius, quod penes te est, poteris agnoscere, quo affectu illum diligere."

${ }^{67}$ De arrha 236.154-55: "Beneficium accipis, et auctorem eius non agnoscit."

${ }^{68}$ De arrha 248.353-56: "O anima mea, si tantopere in incepto persistis, nec tibi satisfactum esse iudicas, si non prorsus singulare beneficium sponsi tui impensum agnoscas, etiam in hoc tue petitioni libenter annuo."

${ }^{69}$ De arrha 272.728-274.731: "Alter per sapientiam illuminatur, alter in simplicitate sui sensus relinquitur; iste ut seipsum despicere, ille ut studeat Creatorem suum agnoscere, utrique tamen uoluit caritas adesse."

${ }^{70}$ De arrha 268.648-50: "quia uehementer illi placere cupio, cuius caritatem erga me tam benignam et amorem tam iocundum agnosco."

${ }^{71}$ De arrha 260.515-17: "Nunquam tam bene dilectionem eius agnoscerem, si in tantis periculis eam experta non fuissem."
}

Speculum 95/1 (January 2020) 
wisdom, pleasing speech, tenacious memory, convincing teaching) and the Soul loves him because of those gifts. However, within our lives, we undergo difficult times and we sin as well, but the Lord still has consoled, comforted, and corrected each person individually. ${ }^{72}$ Although the Soul may understand the idea of individual love described above and even start to desire it, the Soul is not able to recognize the singular aspect of this love and of the gift without experiencing a personal emotional attachment, which is vividly described as the Soul's tasting the sweetness of the spouse. ${ }^{73}$ The core meaning of the betrothal gift is that the spouse who in the future will give himself to the Soul to see and possess unendingly sometimes offers himself to the Soul as a foretaste, in which the Soul may recognize how sweet the spouse is. ${ }^{74}$

The performative element of recognition is clearly manifest in the final part of the Soliloquy, where the Soul at last recognizes God's love and makes a confession. ${ }^{75}$ An important precondition for recognition emerges in the Soul's confession that the Lord himself has given the Soul an ability to recognize the Lord and to understand divine things. ${ }^{76}$ This same idea of God's downward initiative appears in The Praise of the Bridegroom, in which God's bestowal of gifts is said to illuminate the Soul, making it recognize what it is. ${ }^{77}$ Renewal or transformation, and even a sense of spiritual well-being or ecstasy, accompanies the Soul's confession. ${ }^{78}$ The confession and the treatise itself end with the Self encouraging the Soul to make a confession and recognize God: "Recognize the One, love the One, lay hold of the One, and possess the One." 79

The act of recognition is not always situated in the relationship between the Soul and God, however. At times Hugh also uses the idea of recognition in reference to self-reflexive assessment, in which a person is said to obtain knowledge about her inner spiritual state and its functioning. In the initial stages of spiritual learning, the person cannot yet respect her own value in comparison with the external objects of the world because, in her erroneous self-evaluation, the Soul does not recognize her blameworthiness. ${ }^{80}$ Hugh maintains that, instead of loving things beneath

\footnotetext{
${ }^{72}$ De arrha 274.744-46: "Neque enim contentus fuit eadem, que et ceteris, bona nobis tribuere, sed in malis quoque nostris eum singularem dilectorem agnoscimus, ut eum tam de bonis quam sed in malis nostris omnibus singulariter diligamus."

${ }^{73}$ De arrha 248.354-250.366; 282.863-866.

${ }^{74}$ De arrha 282.868-71: "Et hoc est quod maxime ad arram desponsationis tue pertinet, quod ille, qui in futuro se tibi uidendum et perpetuo possidendum dabit, nunc aliquando, ut quam dulcis sit agnoscas, se tibi ad gustandum prebet."

${ }^{75}$ In an Augustinian formulation of the concept, confession (confessio) has three meanings: (1) confession of faith; (2) confession of sins; and (3) confession of praise. See On Love, 231 n. 44.

${ }^{76}$ De arrha 274.748-49: "Tu dedisti michi, Domine, ut te agnoscam et pre ceteris multis de tuis secretis reuelata intelligam."

${ }^{77}$ Eulogium sponsi et sponsae (De amore sponsi ad sponsam), PL 176:988B: "Ideo in omnibus gratias agere debemus, ut dum ubique ipsius misericordiam agnoscimus semper in ejus amore proficiamus."

${ }^{78}$ De arrha $280.844-282.860$.

${ }^{79}$ De arrha 282.873-75: "Queso, anima mea, multa iam diximus: post hec omnia unum agnosce, unum dilige, unum sequere, unum apprehendere, unum posside."

${ }^{80}$ De arrha 230.78-80: "O si faciem tuam uideres, agnosceres certe quanta reprehensione digna fueras, cum aliquid extra te amore tuo dignum existimabas!"
}

Speculum 95/1 (January 2020) 
oneself, it is necessary that each one consider herself and recognize her own dignity. ${ }^{81}$ These examples pinpoint the need to establish a good relation with one's own soul and the importance of cultivating good self-knowledge as well as the right kind of positive emotional attachment towards oneself. ${ }^{82}$

It should be pointed out that in Hugh's treatises, the relation between God and his creatures is very unequal; they are infinitely and absolutely uneven partners. This inequality raises an interesting question about how to find the necessary common ground that must exist between close partners or friends: how is the intimate relationship between God and soul made possible? As Aristotle notes in his Nicomachean Ethics (1159a), it is unthinkable for God and human beings to be "friends," since when one party exists at a great remove, as God does, friendship is impossible. Hugh does not directly address this dilemma in De arrha, but later theologians, including Thomas Aquinas, made the attempt. ${ }^{83}$ Modern theories of recognition allow a certain amount of inequality in recognition relations. Acts of recognition may include asymmetrical power relations, since a person or institute at a higher hierarchical level may recognize a person at a lower level; for example, parents can be said to recognize their child. The intellectual history of recognition includes examples of both upward and downward moves towards the other in acts of recognition. ${ }^{84}$

\section{CONCLUSION}

In his Struggle for Recognition, Axel Honneth builds his comprehensive theory of recognition by combining elements of modern social theory with a historical reading of Hegel's account and by applying the psychological insights of G. H. Mead. Honneth maintains that self-confidence, self-respect, and self-esteem, three modes of relating to oneself, are essential for identity formation. They can be acquired and maintained intersubjectively, through recognition by others whom one also recognizes. These practical modes of relating to the self involve the beliefs one has about oneself, one's emotional states, and one's experience of having a particular status. Only self-confidence, which is supported by love, is a universal precondition for self-realization in any community. However, the notions both of respect and of esteem have gone through significant historical transformations. ${ }^{85}$ My study is based

\footnotetext{
${ }^{81}$ De arrha 232.99-101: "Primum igitur necesse est ut quisquis semetipsum consideret et, cum cognoverit dignitatem suam, ne iniuriam faceret amori suo."

${ }^{82}$ Honneth explains this consciousness of one's worth as referring to a practical positive attitude towards oneself: see Honneth, Struggle for Recognition, 79, 87, 103-7. This positive attitude towards oneself requires that the members of the community recognize the person as of a particular kind. Here Honneth builds his account on George Herbert Mead's influential observations in social psychology. The dimension of love is prior to other forms of recognition and constitutes a fundamental level of emotional confidence. For recognizing oneself, see also Saarinen, Recognition, 32-33, and his further reference to Ricoeur.

${ }^{83}$ See Daniel Schwartz, Aquinas on Friendship (Oxford, 2007), esp. chapter 3.1.2. On the love of God as a friend, see also n. 61 above.

${ }^{84}$ For asymmetrical relations in recognition acts, see Ikäheimo and Laitinen, "Analyzing Recognition." In the medieval context, for example, the theology of Bernard of Clairvaux offers an illustration of spouse/God commending the bride and the bride/soul recognizing her God. See Saarinen, Recognition, 63-69, 186-88.

${ }^{85}$ Honneth, Struggle for Recognition, x-xiv.
}

Speculum 95/1 (January 2020) 
on this realization in asking how practical modes of relating to the self and to identity formation were explained in medieval religious writings.

Hugh of Saint-Victor's studies on human psychology, self-assessment, and one's relation to oneself and God represent a unique contribution. Although the basic orientation and context of his texts differ markedly from contemporary discussions, similarities and common issues can be found. My principal argument in this article has been that the formation of identity within a dialogical encounter and the need to be individually loved or recognized as a person are central concepts in both modern recognition texts and Hugh's treatises.

Furthermore, I have briefly demonstrated how Hugh's Soliloquy contains an early formulation of the relationship between the representative of the upper hierarchy (God) and the lower hierarchy (the Soul) through the use of terminology related to recognition. In medieval feudovassalic bonds, recognition was typically conceived as a relationship between a lord and a servant or between a bridegroom and a bride. In this relationship, the exchange of favors and benefits was thought to constitute recognition. Within Hugh's treatise, this paradigmatic setting is introduced into a theological explanation of the relationship between the Soul and God. In contrast to feudal legal acts and marriage contracts, this spiritual element in Hugh's treatise explores the psychological dimension as part of the recognition act. The allegiance between an individual and God encompasses a subjective experiential dimension in the form of affective involvement. The basic point of departure for the recognition act is the soul's need to be individually loved as special and unique.

Ritva Palmén is a postdoctoral research fellow at the Helsinki Collegium for Advanced Studies, University of Helsinki (e-mail: ritva.palmen@helsinki.fi) 